\title{
SOCIO-ECONOMIC CONDITIONS OF REALIZING YOUTH LEADERSHIP POTENTIAL IN UKRAINE'S UNITED TERRITORIAL COMMUNITIES
}

\section{СОЦІАЛЬНО-ЕКОНОМІЧНІ УМОВИ РЕАЛІЗАЦІЇ ЛІДЕРСЬКОГО ПОТЕНЦІАЛУ МОЛОДІ В ОБ'ЄДНАНИХ ТЕРИТОРІАЛЬНИХ ГРОМАДАХ УКРАЇНИ}

\author{
Natalija Moroziuk ${ }^{1}$ \\ Svitlana Sliusar ${ }^{2}$
}

DOI: https://doi.org/10.30525/978-9934-588-15-0-37

Abstract. The purpose of the paper is to esearch of socio-economic conditions of realization of leadership qualities of youth of the united territorial communities of Ukraine. The research conducted during 2018 2019 revealed the priority factors that have a decisive influence on the decision of young people when choosing their place of permanent residence: availability of jobs, proper living and living conditions; accessibility to quality social services (medical, educational, cultural, etc.). Methodology. In 2019127 young leaders of the united territorial communities of different regions of Ukraine (Ternopil, Lviv, Khmelnytsky, Kyiv, Zhytomyr, Vinnytsia, Lugansk, Dnipropetrovsk) were interviewed regarding the assessment of their socio-economic capacity to realize their leadership qualities. It was conducted during the visit of local self-government bodies of the united territorial communities, as well as educational institutions located in their territories. As a result, an integral index of the conditions for realizing the leadership potential of the youth of the united territorial communities for the western, eastern, southern, northern and central regions of Ukraine is determined. For this purpose the method of its calculation was developed. The integral index is proposed to be calculated as the sum of point estimates of the partial indexes of the integral index of employment at the place of

\footnotetext{
${ }^{1}$ Candidate of Economic Sciences, Associate Professor, Leading Researcher,

National University of Life and Environmental Sciences of Ukraine, Ukraine

${ }^{2}$ Candidate of Economic Sciences, Associate Professor,

Pereiaslav-Khmelnytskyi Hryhorii Skovoroda State Pedagogical University, Ukraine
} 
residence, the integral index of estimation of living and living conditions, the integral index of the estimation of accessibility to quality social services. Each of these integral indices will consist of the sum of partial scores divided by 100 . The maximum value of each can be equal to 1 , the minimum 0 . The results of the poll confirmed that the best starting conditions for realizing leadership potential are in the western regions of Ukraine (Ternopil, Lviv and Khmelnitsky). It is here that the best conditions are created to create jobs in various fields and to provide the right social and living conditions. With regard to the availability of social services, the best situation is in the south-eastern part of Ukraine, in particular the Dnipropetrovsk region, and the worst in the northern and central part of Ukraine. A more detailed analysis showed that the highest employment rate of young people in their place of residence and better living conditions in central and northern Ukraine. According to the youth, the most accessible medical, educational and sports services are in the Western regions, and the higher quality Dnipropetrovsk region. Practical implications. On the basis of the obtained results, the proposals for the united territorial communities of Ukraine on priority directions of creation of favorable socio-economic conditions for realization of its leadership qualities were developed taking into account regional peculiarities of the proposals. Value/originality. The survey of young leaders helped them to better understand their needs and propose more effective measures to create favorable socio-economic conditions for them.

\section{1. Ветуп}

В сучасних умовах реформування системи місцевого самоврядування та адміністративно-територіального устрою в Україні, особливо гостро постала потреба у компетентних і активних фахівцях, здатних швидко і уміло визначати цілі своєї діяльності, прогнозувати досягнення, долати труднощі, будувати взаємини 3 людьми, працювати в команді, тобто повною мірою проявляти свій творчий потенціал і лідерські властивості особистості. Проте кількісне зменшення населення України (насамперед в сільській місцевості), вікова деформація його структури у поєднанні з погіршенням стану здоров'я і скороченням тривалості життя призводить до деградації людського капіталу. Так, у 2018 р. за індексом людського потенціалу Україна посіла 88 місце, в той час як у 2010 р. займала 69 місце. 
На сьогодні в Україні молоді люди віком від 14 до 35 років становлять третину загальної чисельності населення, що позиціонує її як країну із доволі значною кількістю молодого населення. Проте за існуючих умов протягом найближчого десятиліття слід очікувати зменшення цієї вікової категорії населення ще на 3-3,5 млн осіб. Так, якщо у 1990 р. кількість дітей віком до 18 років становила 13,3 млн осіб, то у 2017 р. вже 7,6 млн осіб або 57,1\% рівня 1990 р. Крім того, не маючи змоги реалізуватися в Україні молодь змушена покидати ії. За різними оцінками, до 50\% молоді у віці від 14 до 34 роки мають намір виїхати за кордон. Наразі за даними країн ЄС на їх території офіційно працює або навчається 4 млн українців, половина 3 них в Польщі.

В таких умовах для подолання, а в подальшому запобігання емігрантським настроям, Україні життєво важливо виробити такий механізм реалізації лідерського потенціалу молоді, який би був спрямований на всебічне створення комфортних умов іiї життя на всій території держави та задіяв усі зацікавлені сторони (органи державної влади, місцевого самоврядування, бізнесу, громадськості, вузів тощо).

\section{2. Методика оцінки соціально-економічних умов реалізації лідерського потенціалу молоді обєднаних територіальних громад}

У процесі проведення нами емпіричних досліджень (зокрема круглого столу «Як громаді активізувати молодих лідерів?» [1], а також численних зустрічей з молодими людьми під час відвідання територіальних громад у різних регіонах України) було з'ясовано, що для успішної реалізації свого потенціалу, молодь ОТГ серед усього різноманіття соціально-економічних чинників виділяє три, які є, на іiї думку, ключовими, а саме:

зайнятість за місием проживання;

належні житлово-побутові умови;

доступність до якісних сочіальних послуг (медичних, освітніх, культурних тощо).

Саме ці три чинники були покладені в основу методики визначення інтегрального індексу умов реалізації лідерського потенціалу молоді ОТГ ( $\mathrm{I}_{\text {умр }}$ (ф. 1). Для його розрахунку, виходячи з стану статистичного обліку в Україні, найбільш доцільно використовувати суму бальних оцінок часткових показників (формула 1), які наведені в табл. 1. 


$$
\text { Іумр }=\frac{(\text { Ізм }+ \text { Іжу }+ \text { Ідсп })}{3}
$$

Цей показник складається з трьох блоків:

- інтегрального індексу зайнятості молоді за місцем проживання $\left(\mathrm{I}_{3 м}\right)$;

- інтегрального індексу оцінки житлово-побутових умов $\left(\mathrm{I}_{\text {жу }}\right)$;

- інтегрального індексу оцінки доступності до якісних соціальних послуг $\left(\mathrm{I}_{\text {дсп }}\right)$.

Кожен 3 цих інтегральних індексів буде складатися із суми балів часткових показників (наведених в табл. 1) поділеної на 100. Максимальне значення кожного 3 них може дорівнювати 1 , мінімальне 0.

Таблиця 1

Показники для визначення інтегрального індексу умов реалізації лідерського потенціалу молоді ОТГ

\begin{tabular}{|c|c|}
\hline Показник & Бали \\
\hline \multicolumn{2}{|l|}{$\begin{array}{l}\text { I. Зайнятість молоді за місцем } \\
\text { проживання }\end{array}$} \\
\hline Рівень зайності & $\begin{array}{l}\text { Менше } 25 \%-0,25-50 \%-4,50-75 \%-6 \text {, } \\
75-95 \%-8,95 \% \text { і більше } 10\end{array}$ \\
\hline Наявність вакансій & Не має $-0, €-10$ \\
\hline $\begin{array}{l}\text { Наявність земель несількогосподар- } \\
\text { ського призначення, які можна надати } \\
\text { в оренду молодим підприємцям }\end{array}$ & Не має $-0, €-20$ \\
\hline $\begin{array}{l}\text { Наявність сільськогосподарських угідь, } \\
\text { які можна надати молодим підприємця }\end{array}$ & Не має $-0, €-20$ \\
\hline $\begin{array}{l}\text { Наявність вільних земельних ділянок, } \\
\text { які можна надати в оренду молодим } \\
\text { підприємцям }\end{array}$ & Не має $-0, €-20$ \\
\hline $\begin{array}{l}\text { Рівень неформальної зайнятості серед } \\
\text { молоді, \% }\end{array}$ & $\begin{array}{l}\text { Не має }-20 \text {, менше } 25 \%-15,25-50 \%-10 \text {, } \\
50-75 \%-5,75-95 \%-2,95 \% \text { і більше } 0\end{array}$ \\
\hline \multicolumn{2}{|l|}{ Разом по I блоку } \\
\hline \multicolumn{2}{|l|}{ ІІ. Житлово-побутові умови } \\
\hline $\begin{array}{l}\text { Відсоток молодих домогосподартсв, } \\
\text { які володіють власним житлом }\end{array}$ & $\begin{array}{l}\text { Не має }-0, \text { менше } 25 \%-2,25-50 \%-4, \\
50-75 \%-6,75-95 \%-8,95 \% \text { і більше } 10\end{array}$ \\
\hline $\begin{array}{l}\text { Будівництво нового житла (введення } \\
\text { житла забудовниками усіх форм } \\
\text { власності), \% до загального житлогово } \\
\text { фонду }\end{array}$ & $\begin{array}{l}\text { Не має }-0 \text {, менше } 25 \%-2,25-50 \%-4, \\
50-75 \%-6,75-95 \%-8,95 \% \text { і більше } 10\end{array}$ \\
\hline
\end{tabular}


Закінчення таблиці 1

\begin{tabular}{|c|c|}
\hline Показник & Бали \\
\hline Рівень газифікації, \% & $\begin{array}{l}\text { Не має }-0, \text { менше } 25 \%-2,25-50 \%-4, \\
50-75 \%-6,75-95 \%-8,95 \% \text { і більше } 10\end{array}$ \\
\hline $\begin{array}{l}\text { Рівень охоплення домогосподарств } \\
\text { централізованим водопостачанням, \% }\end{array}$ & $\begin{array}{l}\text { Не має }-0, \text { менше } 25 \%-2,25-50 \%-4, \\
50-75 \%-6,75-95 \%-8,95 \% \text { і більше } 10\end{array}$ \\
\hline $\begin{array}{l}\text { Рівень охоплення домогосподарств } \\
\text { централізованим водовідведенням, \% }\end{array}$ & $\begin{array}{l}\text { Не має }-0, \text { менше } 25 \%-2,25-50 \%-4, \\
50-75 \%-6,75-95 \%-8,95 \% \text { і більше } 10\end{array}$ \\
\hline $\begin{array}{l}\text { Наявність мобільного звязку та швид- } \\
\text { кісного інтернету }\end{array}$ & $\begin{array}{l}\text { Не має }-0 \text {, Часткове покриття терито- } \\
\text { piï }-5 \text {, Повне покриття }-10\end{array}$ \\
\hline Вуличне освітлення & Не має - 0 , Часткове -5, С повністю - 10 \\
\hline Стан доріг & $\begin{array}{l}\text { Незадовільний }-0, \text { Задовільний }-5, \\
\text { Гарний }-10\end{array}$ \\
\hline Громадська безпека & $\begin{array}{l}\text { Незадовільна }-0, \text { Задовільна }-5, \\
\text { Наявність діючого центру безпеки }-10\end{array}$ \\
\hline Організований вивіз сміття & Не має -0, Частково $-5, €$ повністю -10 \\
\hline \multicolumn{2}{|l|}{ Разом по II блоку } \\
\hline \multicolumn{2}{|l|}{$\begin{array}{l}\text { III. Доступність до якісних соціаль- } \\
\text { них послуг }\end{array}$} \\
\hline $\begin{array}{l}\text { Наявність центру первинної медичної } \\
\text { допомоги }\end{array}$ & $\begin{array}{l}\mathrm{Hi}-0 \text { В процесі будівництва }-5 \text { Так } \\
\epsilon-10\end{array}$ \\
\hline $\begin{array}{l}\text { Забезпеченість центру первинної } \\
\text { медичної допомоги лікарями, \% }\end{array}$ & $\begin{array}{l}\text { Менше } 50 \%-0,50-75 \%-5,75-95 \%- \\
8,95 \% \text { і більше } 10\end{array}$ \\
\hline $\begin{array}{l}\text { Рівень охоплення дітей дошкільною } \\
\text { освітою, \% }\end{array}$ & $\begin{array}{l}\text { Менше } 25 \%-0,25-50 \%-4,50-75 \%-6, \\
75-95 \%-8,95 \% \text { і більше } 10\end{array}$ \\
\hline $\begin{array}{l}\text { Наявність школи, яка відповідає стан- } \\
\text { дартам Нової української школи }\end{array}$ & $\begin{array}{l}\text { Не відповідає зовсім - } 0, \text { Відповідає } \\
\text { частково - } 5, \text { Відповідає повністю - } 10\end{array}$ \\
\hline Забезпеченість школи вчителями, \% & $\begin{array}{l}\text { Менше } 50 \%-0,50-75 \%-5,75-95 \%-8, \\
95 \% \text { і більше } 10\end{array}$ \\
\hline $\begin{array}{l}\text { Наявність гуртків, факультативів, } \\
\text { спецкурсів на території громади }\end{array}$ & Нi - 0 В процесі створення -5 Так $€-10$ \\
\hline $\begin{array}{l}\text { Навність діючого сучасного будинку } \\
\text { культури }\end{array}$ & $\begin{array}{l}\mathrm{Hi}-0 \text { В процесі будівництва }-5 \text { Так } \\
\epsilon-10\end{array}$ \\
\hline $\begin{array}{l}\text { Наявність урбаністичних місць для } \\
\text { проведення дозвілля }\end{array}$ & $\begin{array}{l}\mathrm{Hi}-0 \text { В процесі будівництва }-5 \text { Так } \\
\epsilon-10\end{array}$ \\
\hline Наявність спортивних секцій & Нi - 0 В процесі будівництва -5 Так $€-10$ \\
\hline Наявність спортивних площадок & Ні-0 В процесі будівництва -5 Так $\epsilon-10$ \\
\hline \multicolumn{2}{|l|}{ Разом по ІІІ блоку } \\
\hline ВСЬОГО & \\
\hline
\end{tabular}

Джерело: авторська розробка 
3. Аналіз основних умов реалізації лідерського потенціалу молоді обєднаних територіальних громад в Україні

I. Зайнятість за місцем проживання. Основною причиною, яка $€$ визначальною при прийнятті рішення про не повернення в свою ОТГ після навчання та міграцію є відсутність робочих місць. Так, рівень зареєстрованого безробіття найвищий серед молоді - у віці 15-24 роки $23 \%$ та 25-29 років 11,7\%. Крім того, серед цієї вікової категорії $є$ поширеною неформальна зайнятість, у сільській місцевості ії рівень досягає $40 \%$ (рис. 1$)$.

Як наслідок, складної ситуації на ринку праці, серед домогосподарств, які мають доходи нижче прожиткового мінімуму, третина зайняті. При цьому слід наголосити на тому, що в Україні ризиком зниження рівня матеріального добробуту сім'ї $є$ народження дитини, що змушує майже дві третини жінок працювати поєднуючи материнство з роботою.

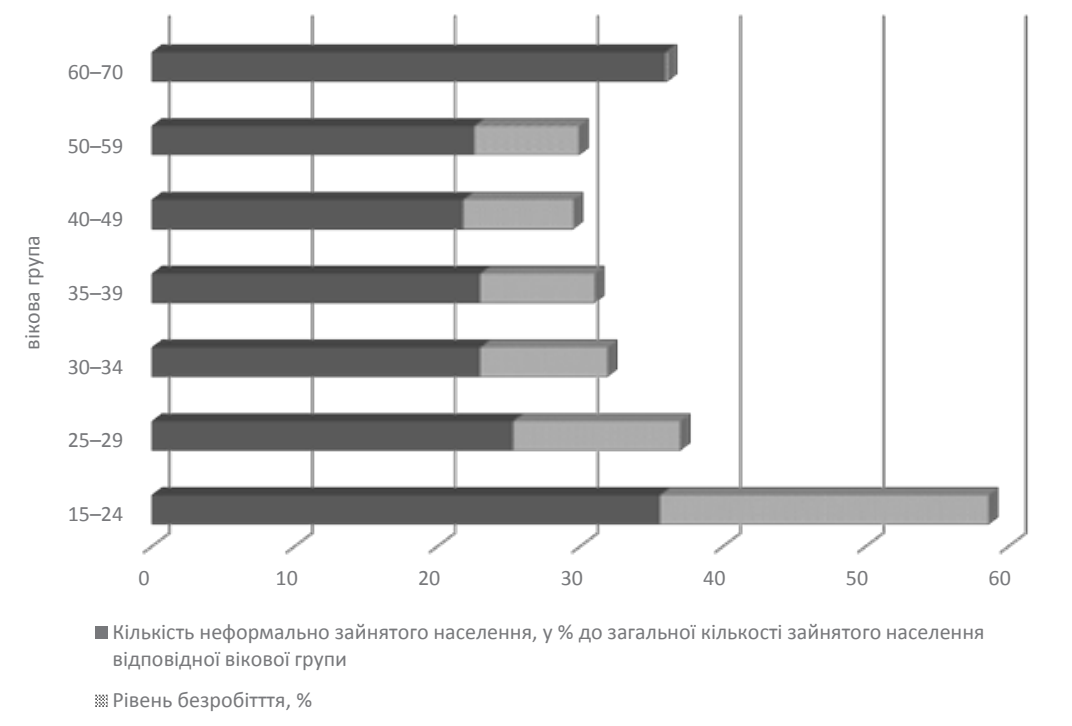

Рис. 1. Рівень неформальної зайнятості та рівень безробіття різних вікових груп населення України у 2016 р., \%

Джерело: побудовано за даними Державної служби статистики Украӥни [2] 
Ускладнює ситуацію на українському ринку праці існуюча дискримінація за віком, що підтверджують статистичні дані. Але якщо про проблеми з працевлаштуванням осіб передпенсійного віку суспільство активно обговорює і намагається законодавчо врегулювати, то стосовно молоді ситуація досить складна.

Норм трудового законодавства щодо захисту цієї вікової групи не дотримуються. Це вже в найближчому майбутньому може мати негативні наслідки як для держави, так і окремих роботодавців. Так, відомо, що для успішного функціонування підприємства важливо дотримуватись балансу - кількість молодих людей та осіб передпенсійного віку повинна бути більш менш рівною. У цьому випадку відбувається передача досвіду, в іншому цей процес порушується.

Порівняно із середнім рівнем безробіття серед молоді в країнах $\mathrm{CC}$, що становить близько $23 \%$, а в деяких країнах він досягає відмітки $50 \%$, рівень безробіття в Україні не $\epsilon$ високим. Але досвід безробіття серед молодих людей може бути більш руйнівним для молодого покоління України, оскільки їхні батьки мають менше можливостей економічно підтримувати своїх дітей.

II. Належні житлово-побутові умови. Третина домогосподарств в Україні незадоволені своїм житловими умовами. Кожна п'ята молода сім'я не має власного окремого житла. Загалом у перенаселених житлових приміщеннях проживає 54\% населення України.

Низькою є якість цих житлових приміщень, як в більшості випадків потребують капітального ремонту - майже кожне п'яте домогосподарство проживає у житлі, збудованому до 1960 р., після 1991 р. - 12\% домогосподарств. Централізованим газопостачанням користуються $78 \%$ домогосподарств, балонним газом - 12\%. Газову колонку у своєму житлі мають 15\%, гаряче водопостачання - 40\% домогосподарств. Водопроводом і каналізацією обладнано житло 80\% домогосподарств, ванну або душ мають 76\% домогосподарств. При цьому в сільській місцевості ці показники істотно нижчі.

Основною проблемою для старшої групи молоді, що знаходиться у віці 25-35 років, є співвідношення доходів від праці та вартості життя (зокрема, житла). Процес виходу молодих подружніх пар з батьківських сімей є повільним та вельми складним, через невирішеність житлових проблем, нездатність більшості населення купувати або 
орендувати житло та через загальний дисбаланс між цінами на ринку житла та реальними доходами як молоді, так і літніх людей. Невирішені проблеми з житлом $є$ одним з основних чинників затримки шлюбу та дітонародження.

\section{III. Доступність до якісних соціальних послуг (медичних, освіт-} нix, культурних тощо). Щодо доступності медичних послуг для молоді ОТГ, то ситуація у результаті реформування первинної ланки системи охорони здоров'я та спрямування державних коштів на і1і розбудову може істотно поліпшитися. Стосовно дозвілля молоді, то його намагаються урізноманітнити численні молодіжні та дитячі центри, бурхливий розвиток, яких спостерігається останніми роками.

Слід звернути увагу, що сільські діти через раніше виходять на ринок праці - 32,1\% молоді у віці 15-24 роки працює, в той час як у містах їх 24,1\%. Після 25 років ситуація змінюється на протилежну в сільській місцевості рівень зайнятості на рівні 66,3-68,5\%, а в міських поселеннях 71,5-77,0\%.

Таку ситуацію можна пов'язати 3 кількома причинами: по-перше недоступність вищої освіти для сільської молоді через брак фінансових ресурсів та по-друге, низькою якістю отриманих знань. Так, кожен п’ятий випускник сільської школи не долає при проходженні зовнішнього незалежного оцінювання не долає мінімальний поріг, необхідний для вступу у заклади вищої освіти.

Проте як свідчать дані табл. 2 в галузі освіти спостерігається ряд негативних тенденцій. Так, кількість учнів за останні 27 років скоротилася на $45 \%$, в той час як мережа закладів загальноосвітніх закладів на 25,7\%, а кількість вчителів на 19,1\%. Якщо в 1990/1991 н.р. кількість учнів у розрахунку на 1 вчителя становила 13 осіб, то вже у 2017/2018 н.р. 9 осіб.

Це призводить до неефективного використання коштів на шкільну освіту, що відчули на собі об'єднані територіальні громади, які перебрали на себе управління освітніми закладами. Органи місцевого самоврядування, як і мешканці громад почали усвідомлювати необхідність оптимізації мережі освітніх закладів, які знаходяться на їх території, та перегляду штатів педагогічних працівників.

Слід відмітити, що ситуація з кількісними показниками в освітній галузі найближчими роками не покращиться, хоч і рівень народжува- 
ності в Україні зріс. А це в свою чергу призведе до негативних наслідків у вищій освіті, Так, кількість випускників у 2018 р. порівняно 3 1991 р. скоротилася вдвічі, водночас кількість закладів вищої освіти III - IV рівнів акредитації збільшилася майже удвічі. Якщо у 1991 р. середня кількість випускників у розрахунку на 1 такий заклад становила 2725 осіб, то у 2018 р. вже 703 особи, що становить 25\% від рівня 1990 р. Якщо врахувати кількість осіб, які не здають ЗНО або не подолали мінімальний поріг, необхідний для вступу у заклади вищої освіти, то цей показник можна скоротити ще на 25-30\%.

Таблиця 2

\section{Основні показники галузі освіти України,}

на початок навчального року

\begin{tabular}{|l|c|c|c|c|}
\hline \multirow{2}{*}{ Показник } & \multicolumn{3}{|c|}{ Навчальний рік } & \% 2017/2018 \\
\cline { 2 - 5 } & $\mathbf{1 9 9 0 / 1 9 9 1}$ & $\mathbf{2 0 1 3 / 2 0 1 4}$ & $\mathbf{2 0 1 7 / 2 0 1 8}$ & до 1990/1991 \\
\hline $\begin{array}{l}\text { Кількість загальноосвітніх } \\
\text { навчальних закладів, тис. од. }\end{array}$ & 21,8 & 19,3 & 16,2 & 74,3 \\
\hline Кількість учителів, тис. осіб & 537 & 508 & 440 & 81,9 \\
\hline Кількість учнів, всього, тис. осіб & 7132 & 4204 & 3922 & 55,0 \\
\hline $\begin{array}{l}\text { Кількість учнів у розрахунку, } \\
\text { осіб: }\end{array}$ & & & & \\
\hline на 1 заклад & 327 & 218 & 242 & 74,0 \\
\hline на 1 учителя & 13 & 8 & 9 & 69,2 \\
\hline $\begin{array}{l}\text { Кількість вищих навчальних } \\
\text { закладів III-ІV рівнів акреди- } \\
\text { тації, од. }\end{array}$ & 149 & 325 & 289 & 194,0 \\
\hline $\begin{array}{l}\text { Кількість випускників школи } \\
\text { III ступеня загальноосвітніх } \\
\text { навчальних закладів, тис. осіб- } \\
\text { всього }\end{array}$ & 406 & 304 & 203 & 50,0 \\
\hline $\begin{array}{l}\text { у розрахунку на 1 вищих } \\
\text { навчальний заклад III-ІІV } \\
\text { рівнів акредитації, осіб }\end{array}$ & 2725 & 936 & 703 & 25,8 \\
\hline
\end{tabular}

Джерело: розраховано за офіиійними даними Держсавної служби статистики України [2] та Міністерства освіти і науки Украӥни [3, с. 6]

Проблемою, з якою зіштовхнулися заклади вищої освіти України в останнє десятиліття, є міграція потенційних абітурієнтів. Так, 55\% молодих 
людей у віці від 18 до 29 років мають намір покинути Україну, кожен третій українець розглядає можливість виїхати з країни прямо зараз. $34,5 \%$ жителів малих містечок, $26 \%$ сільських жителів та $25 \%$ жителів селищ готові покинути свої місця проживання в Україні і мігрувати в інші країни.

32003 року кількість студентів, які навчаються у вузах України зменшилася на 34\%. Динаміка кількості вищих навчальних закладів за останні 15 років має тенденцію до спаду: кількість закладів III-IV рівня акредитації скоротилася на 50 од., I-II рівня акредитації наполовину. За даними Міністерства освіти і науки України, у 2015/2016 н. p. - 66,7 тис. молодих українців навчалися за кордоном, причому їх кількість за останні 5 зросла на 176\%. Дві третини цього приросту склали студенти, які навчаються в польських університетах.

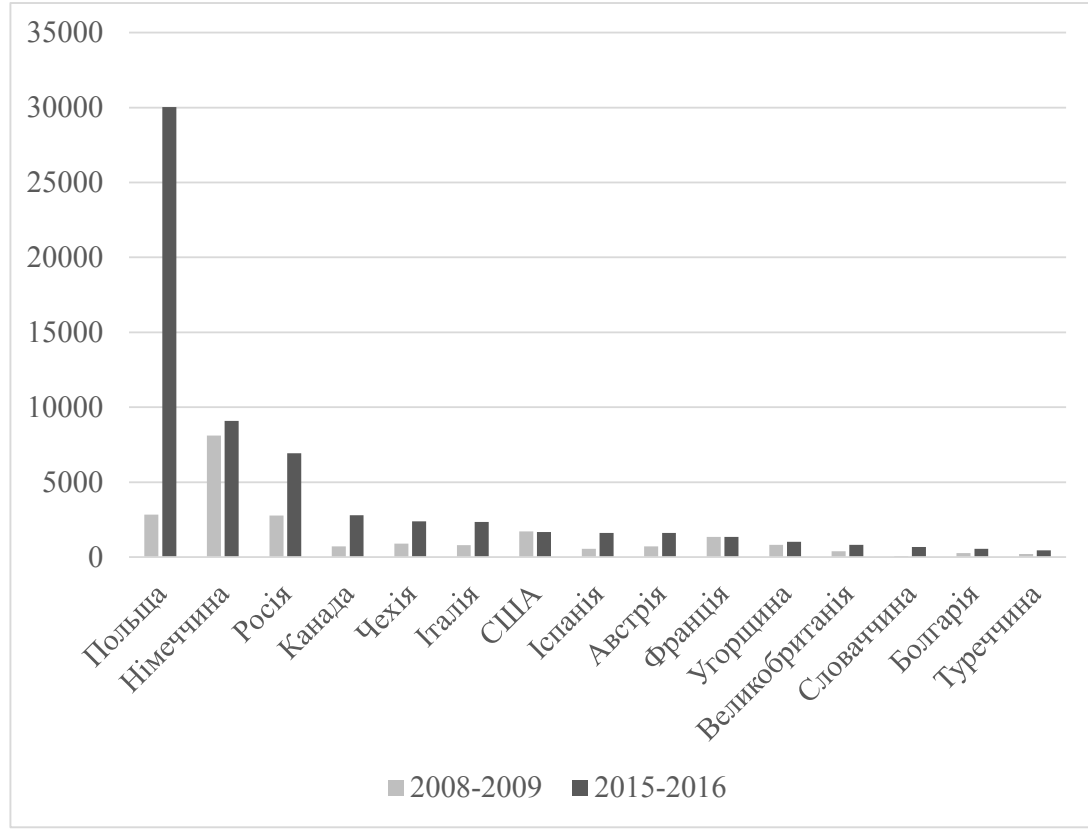

Рис. 2. Кількість українських студентів за кордоном на денній формі навчання за окремими країнами, осіб

Джерело: за даними Міністерства освіти і науки України [3, с. 14] 
Серед найбільш бажаних для навчання країн, як і раніше, залишаються Польща, Німеччина, Росія, Канада, Італія, Чехія, США, Іспанія, Австрія, Франція та Угорщина. Динаміка зростання з 2009 по 2016 роки склала 176\%. Якщо порівнювати два останні роки, то приріст складає майже 20\% або ж 10934 осіб. Причому 2/3 цього приросту склали саме українці, які навчаються в польських університетах. Вони показали найбільш стрімке збільшення, як в абсолютному, так і відносному показниках, - 322833 до 30041 особи (майже 32\%). Також значний відносний та абсолютний приріст українських громадян на студіях демонстрували канадські, словацькі та італійські університети.

Деякі країни не беруть плати за навчання з іноземних студентів. Наприклад, у Німеччині, якщо ви навчаєтесь на німецькомовній програмі у державному університеті, ви не будете сплачувати за навчання, окрім зборів за реєстрацію та страхування, які є радше символічними. Подібна ситуація у чеських та французьких державних університетах.

В інших країнах загалом навчання $є$ платним, проте $є$ спеціальні умови, за яких іноземний студент звільняється від плати. Наприклад, у Польщі, якщо у вас $є$ карта поляка, тобто офіційно визнане польське коріння, ви також можете навчатись безоплатно у державних університетах. Втім лише десята частина українських студентів у польських університетах має таке право.

Окрім цього часто країни чи окремі університети пропонують стипендії для іноземців, які покривають плату за навчання. Проте їх кількість $є$ незначною. Наприклад, у тій же Польщі такі стипендії отримують менше 5\% українців, які там навчаються. Однак інформація про ці стипендія досить активно поширюється, що створює викривлене враження їх повсюдності.

Проте на загал в Польщі та й у більшості країн, де $\epsilon$ українські студенти, навчання в університетах для іноземців є платним. Зрештою зазвичай іноземні студенти є важливим джерелом заробітку для університетів та навіть цілих країн. Наприклад, саме так є в Україні, де вартість навчання для іноземних студентів є набагато вищою, ніж контрактне навчання для українців.

Тож, попри поширене уявлення, найчастіше українці платять за своє навчання за кордоном зі своєї кишені. Загалом за найбільш опти- 
містичними розрахунками безкоштовно за кордоном навчається не більше чверті українських громадян. У такій ситуації передовсім втрачають українські університети, які недоотримують кошти від студентів, які могли би бути їх контрактниками.

В той же час в умовах реформи децентралізації в Україні утворені більш ніж 900 об’єднаних громад відчувають лідерський та кадровий голод. Найбільше не вистачає кваліфікованих управлінців 3 новим проектним баченням розвитку громади. Понад $40 \%$ фахівців, задіяних в управлінні об'єднаними громадами - це люди старші 45 років, і лише третина молодих людей. Також спостерігається низька лідерська активність серед депутатського корпусу, особливо в сільській місцевості.

3 однієї сторони економічна нестабільність, безробіття та війна не сприяють благополучній реалізації молодих фахівців в Україні. Це посилює загальне переконання про те, що ті, хто вже виїхав на навчання за кордон, навряд чи прагнуть повернутись до України. Однак 3 іншої сторони, ті, хто після навчання намагається залишитись за кордоном, часто зустрічають певні труднощі з працевлаштуванням. Адже деякі країни сприяють виходу на ринок праці іноземних студентів, а деякі - навпаки стримують його.

Вирішення усіх вищеперелічених умов вимагає скоординованої діяльності п’яти ключових суб'єктів управління ОТГ: органами державної влади, місцевого самоврядування, населення, громадського сектору та бізнесу. Для їх злагодженої роботи насамперед потрібна законодавча база. Молодіжна політика в умовах децентралізації має багато орієнтирів для створення комфортного життя. Наразі основоположним документом реалізації молодіжної політики є Державна цільова соціальна програма «Молодь України» на 2016-2020 роки, затверджена постановою Кабінету Міністрів України від 18 лютого 2016 р. № 148 [4].

Крім того в Україні діють різні програми з підтримки молоді та реалізації лідерського потенціалу, але нажаль не всі громади доносять їх до жителів, тому більшість людей не має інформації про них, відповідно і не користується ними. Варто зазначити, що також відсутні відповідні центри мобільності, які б впроваджували б програми безпосередньо у віддалених громадах. 


\section{4. Оцінка регіональних особливостей забезпечення} соціально-економічних умов реалізації лідерського потенціалу

\section{молоді в об'сднаних територіальних громад України}

Протягом 2019 року в обєднаних територіальних громадах України нами проводилося опитування молодих лідерів щодо можливостей реалізації їх потенціалу. Всього було опитано 127 осіб з Тернопільської, Львівської, Хмельницької, Київської, Житомирської, Вінницької, Луганської, Дніпропетровської областей. За вищенаведеною у даній статті методикою було розраховано інтегральний індекс умов реалізації лідерського потенціалу молоді ОТГ для різних регіонів України. Результати представлені у табл. 3.

Таблиця 3

Результати розрахунку інтегрального індексу умов реалізації лідерського потенціалу молоді ОТГ для різних регіонів України

\begin{tabular}{|c|c|c|c|c|}
\hline Інтегральний індекс & 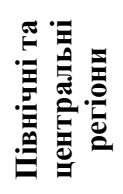 & 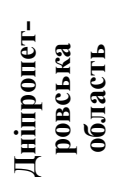 & 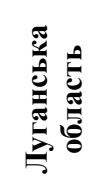 & 局 \\
\hline $\begin{array}{l}\text { I. Інтегральний індекс оцінки } \\
\text { умов для зайнятості молоді за } \\
\text { місцем проживання }\end{array}$ & 0,5934 & 0,5433 & 0,6041 & 0,665 \\
\hline $\begin{array}{l}\text { II. Інтегральний індекс оцінки } \\
\text { житлово-побутових умов }\end{array}$ & 0,5302 & 0,4933 & 0,45 & 0,543 \\
\hline $\begin{array}{l}\text { III. Інтегральний індекс } \\
\text { оцінки доступності якісних } \\
\text { соціальних послуг }\end{array}$ & 0,6962 & 0,7956 & 0,7017 & 0,746 \\
\hline $\begin{array}{l}\text { Зведений інтегральний } \\
\text { індекс оцінки соціально- } \\
\text { економічних умов реалізації } \\
\text { лідерського потенціалу } \\
\text { молоді ОТГ }\end{array}$ & $\mathbf{0 , 6 0 6 6}$ & $\mathbf{0 , 6 1 0 7}$ & $\mathbf{0 , 5 8 5 3}$ & 0,652 \\
\hline
\end{tabular}

Джерело: авторська розробка

Отже, на думку молодих лідерів:

- найкращі вихідні умови для реалізації лідерського потенціалу мають західні області України (Тернопільська, Львівська та Хмель- 
ницька). Саме тут для створення робочих місць у різноманітних сферах та забезпечення належних соціально-побутових умов.

Щодо доступності соціальних послуг, то найкраща ситуація у південно-східній частині України, зокрема Дніпропетровській області, а найгірша в північній та центральній частині України

Найгірші умови для реалізація лідерського потенціалу молоді в Східній Україні.

Більш детальний аналіз оцінки інтегрального індексу умов для зайнятості молоді за місцем проживання для різних регіонів України (табл. 4), підтверджує те, що в центральній та північній частині Україні найбільший рівень зайнятості та найбільша кількість вакансій.

Таблиця 4

Результати розрахунку інтегрального індексу умов для зайнятості молоді за місцем проживання для різних регіонів України

\begin{tabular}{|c|c|c|c|c|}
\hline Показник & 基 & 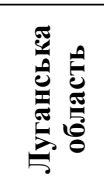 & 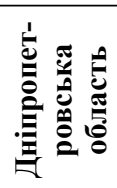 & 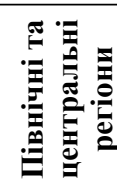 \\
\hline Рівень зайнятості & 0,039 & 0,0247 & 0,0378 & 0,052 \\
\hline Наявність вакансій & 0,067 & 0,0412 & 0,0333 & 0,072 \\
\hline $\begin{array}{l}\text { Наявність земель } \\
\text { несількогосподарського } \\
\text { призначення, які можна надати } \\
\text { в оренду молодим підприємцям }\end{array}$ & 0,133 & 0,1529 & 0,1111 & 0,128 \\
\hline $\begin{array}{l}\text { Наявність } \\
\text { сільськогосподарських угідь, } \\
\text { які можна надати молодим } \\
\text { підприємцям } \\
\end{array}$ & 0,147 & 0,1412 & 0,1111 & 0,1 \\
\hline $\begin{array}{l}\text { Наявність вільних земельних } \\
\text { ділянок, які можна надати в } \\
\text { оренду молодим підприємцям }\end{array}$ & 0,16 & 0,1176 & 0,1556 & 0,14 \\
\hline $\begin{array}{l}\text { Рівень неформальної зайнятості } \\
\text { серед молоді, }\end{array}$ & 0,12 & 0,1265 & 0,0944 & 0,1014 \\
\hline $\begin{array}{l}\text { Інтегральний індекс оцінки } \\
\text { умов для зайнятості молоді } \\
\text { за місцем проживання }\end{array}$ & 0,665 & 0,6041 & 0,5433 & 0,5934 \\
\hline
\end{tabular}

Джерело: авторська розробка 
Такий результат є закономірним через розташування м. Києва та наявності можливостей для молоді знайти висококваліфіковану роботу, яка дозволить розвинути та реалізувати в повній мірі лідерські якості.

Західна Україна має найбільше вільних ділянок, які можна надавати молодим підприємцям в оренду, зокрема сільськогосподарських угідь, а на Сході - для несільськогосподарських видів економічної діяльності.

Закономірним також є те, що саме в центральній та північній частині України найбільше будується житла, а найменше на заході (табл. 5). В центральних регіонах найкращий стан доріг та вуличне освітлення, а найбезпечніше в громадських місцях в західних регіонах. Дніпропетровська область має найкращий інтернет зв'язок та вивіз сміття.

Таблиця 5

Результати розрахунку інтегрального індексу оцінки житлово-побутових умов для різних регіонів України

\begin{tabular}{|c|c|c|c|c|}
\hline Показник & 基 & 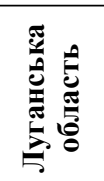 & 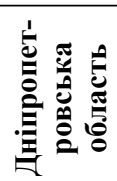 & 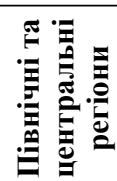 \\
\hline $\begin{array}{l}\text { Відсоток молодих домогосподарств, } \\
\text { які володіють власним житлом }\end{array}$ & 0,04 & 0,0353 & 0,0378 & 0,0428 \\
\hline $\begin{array}{l}\text { Будівництво нового житла } \\
\text { (введення житла забудовниками } \\
\text { усіх форм власності) }\end{array}$ & 0,008 & 0,0177 & 0,0222 & 0,046 \\
\hline Рівень газифікації & 0,084 & 0,08 & 0,0622 & 0,0508 \\
\hline $\begin{array}{l}\text { Рівень охоплення домогосподарств } \\
\text { централізованим водопостачанням }\end{array}$ & 0,065 & 0,0529 & 0,0533 & 0,0572 \\
\hline $\begin{array}{l}\text { Рівень охоплення домогосподарств } \\
\text { централізованим водовідведенням }\end{array}$ & 0,051 & 0,0494 & 0,0511 & 0,0624 \\
\hline $\begin{array}{l}\text { Наявність мобільного зв'язку } \\
\text { та швидкісного інтернету }\end{array}$ & 0,077 & 0,0647 & 0,0778 & 0,072 \\
\hline Вуличне освітлення & 0,07 & 0,0559 & 0,0611 & 0,071 \\
\hline Стан доріг & 0,03 & 0,0088 & 0,0222 & 0,032 \\
\hline Громадська безпека & 0,053 & 0,0441 & 0,0333 & 0,037 \\
\hline Організований вивіз сміття & 0,067 & 0,0412 & 0,0722 & 0,059 \\
\hline $\begin{array}{l}\text { Інтегральний індекс оцінки } \\
\text { житлово-побутових умов }\end{array}$ & 0,543 & 0,45 & 0,4933 & 0,5302 \\
\hline
\end{tabular}

Джерело: авторська розробка 
Найбільш доступні медичні, освітні та спортивні послуги, на думку молоді, мають Західні регіони, а більш якісні Дніпропетровська область. Щодо культурних послуг, то їх якість найкраща на Сході України (табл. 6).

Виходячи $з$ вищевикладеного під час формування стратегій розвитку регіонів та окремих громад для формування сприятливих соціально-економічних умов реалізації лідерського потенціалу молоді слід зосередити увагу на:

- західним областям - розвитку аграрного молодіжного підприємництва та пов'язаних з ним видам економічної діяльності (наприклад, переробка сільськогосподарської продукції); стимулювання будівництва нового або реконструкції існуючого житла молоддю;

Таблиця 6

Результати розрахунку інтегрального індекс оцінки доступності якісних соціальних послуг для різних регіонів України

\begin{tabular}{|c|c|c|c|c|}
\hline Показник & 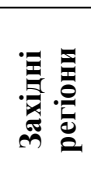 & 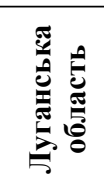 & 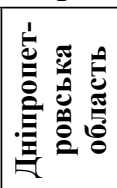 & 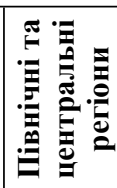 \\
\hline $\begin{array}{l}\text { Наявність центру первинної медичної } \\
\text { допомоги }\end{array}$ & 0,093 & 0,0971 & 0,1 & 0,077 \\
\hline $\begin{array}{l}\text { Забезпеченість центру первинної медичної } \\
\text { допомоги лікарями }\end{array}$ & 0,073 & 0,0406 & 0,0478 & 0,0496 \\
\hline Рівень охоплення дітей дошкільною освітою & 0,079 & 0,0729 & 0,0756 & 0,0596 \\
\hline $\begin{array}{l}\text { Наявність школи, яка відповідає стандартам } \\
\text { Нової української школи }\end{array}$ & 0,073 & 0,05 & 0,0778 & 0,054 \\
\hline Забезпеченість школи вчителями & 0,084 & 0,0705 & 0,0778 & 0,065 \\
\hline $\begin{array}{l}\text { Наявність гуртків, факультативів, } \\
\text { спецкурсів на території громади }\end{array}$ & 0,083 & 0,0647 & 0,0889 & 0,084 \\
\hline Наявність діючого сучасного будинку культури & 0,057 & 0,0882 & 0,0833 & 0,076 \\
\hline $\begin{array}{l}\text { Наявність урбаністичних місць } \\
\text { для проведення дозвілля }\end{array}$ & 0,033 & 0,05 & 0,0722 & 0,074 \\
\hline Наявність спортивних секцій & 0,087 & 0,0912 & 0,1 & 0,075 \\
\hline Наявність спортивних площадок & 0,083 & 0,0765 & 0,0722 & 0,082 \\
\hline $\begin{array}{l}\text { Інтегральний індекс оцінки доступності } \\
\text { якісних соціальних послуг }\end{array}$ & 0,746 & 0,7018 & 0,7956 & 0,6962 \\
\hline
\end{tabular}

Джерело: авторська розробка 
- північним та центральним областям - розвитку соціальної інфраструктури та підвищення комфортності умов проживання. Особливо це стосується регіонів де ведеться активна житлова забудова, при цьому повністю ігнорується зростання навантаження на освітні та медичні заклади;

- Дніпропетровська область - забезпеченні комфортних умов для проживання та створення нових робочих місць. Так як молодь вказала на наявність вільних земельних ділянок, то потрібно зосередитись на розвитку молодіжного підприємництва як сільськогосподарського, так і несільськогосподарського. Також доцільно підвищувати рівень безпеки у громадських місцях;

- східним областям - розвитку молодіжного підприємництва у несільськогосподарських видах діяльності. Щодо решти умов, то вони визначатимуться перебігом військового конфлікту.

\section{5. Висновки}

1. За незмінних умов розвитку України є збереження високого рівня міграції молоді за їі межі, в першу чергу яка має лідерські якості. Подолання негативних тенденцій вимагає створення молодим лідерам таких умов, які б дозволили не тільки забезпечити їм матеріальний добробут на рівні країн $\mathrm{CC}$, але й самореалізуватися у професійному житті. Як було з'ясовано у процесі наших досліджень, молодь ОТГ серед усього різноманіття соціально-економічних чинників виділяє три, які є, на її думку, ключовими, а саме: зайнятість за місцем проживання; належні житлово-побутові умови; доступність якісних соціальних послуг (медичних, освітніх, культурних тощо). Саме ці три чинники були покладені в основу методики визначення інтегрального індексу умов реалізації лідерського потенціалу молоді ОТГ.

2. Високий рівень безробіття у поєднанні з поширенням неформальної зайнятості, спонукають молодь до прийняття рішення про міграцію. Ситуацію ускладнює відсутність окремого від батьків, якісного житла. Також знижується доступність молоді основних соціальних послуг: медичних, освітніх, культурних. Особливо це стосується сільської місцевості.

3. Оцінка регіональних особливостей забезпечення соціально-економічних умов реалізації лідерського потенціалу молоді в об'єднаних 
територіальних громад України, виявила що найкращими вони $є$ в західних областях України, найгіршими в східних. Найвищий рівень зайнятості молоді за місцем проживання та кращі житлово-побутові умови в центральній та північній частині України. Найбільш доступні медичні, освітні та спортивні послуги, на думку молоді, мають Західні регіони, а більш якісні Дніпропетровська область.

Виходячи $з$ отриманих результатів оцінки умов реалізації лідерського потенціалу, розроблені пропозиції для різних регіонів. Усім областям та об'єднаним територіальних громадам запропоновано особливу увагу приділити молодіжній зайнятості та підприємництву, а також створенню комфортних умов проживання для молодих лідерів.

\section{Список літератури:}

1. Як громаді активізувати молодих лідерів? Укрінформ. URL: https://www.ukrinform.ua/rubric-presshall/2441162-ak-gromadi-aktivizuvatimolodih-lideriv.html (дата звернення: 25.10.2019).

2. Офіційний сайт Державної служби статистики України. URL: http://www.ukrstat.gov.ua/ (дата звернення: 8.10.2019).

3. Про міграцію українських студентів на навчання до закордонних університетів: доповідна записка / Колегія Міністерства освіти і науки України. 2018. 34 с.

4. Про затвердження Державної цільової соціальної програми «Молодь України» на 2016-2020 роки: постанова Кабінету Міністрів України від 18 лют. 2016 р. № 148. URL: https://zakon.rada.gov.ua/laws/show/148-2016$\% \mathrm{D} 0 \% \mathrm{BF}$ (дата звернення: 12.10.2019).

\section{References:}

1. Ukrinform (2018). Jak ghromadi aktyvizuvaty molodykh lideriv [How a community can empower young leaders]? URL: https://www.ukrinform.ua/ rubric-presshall/2441162-ak-gromadi-aktivizuvati-molodih-lideriv.html (accessed 25 October 2019).

2. Derzhavna sluzhba statystyky Ukrajiny (2019). Oficijnyj sajt Derzhavnoji sluzhby statystyky Ukrajiny [Official site of the State Statistics Service of Ukraine]. URL: http://www.ukrstat.gov.ua/ (accessed 8 October 2019).

3. Koleghija Ministerstva osvity i nauky Ukrajiny (2018). Pro mighraciju ukrajinsjkykh studentiv na navchannja do zakordonnykh universytetiv [About migration of Ukrainian students to study at foreign universities]: dopovidna zapyska. $34 \mathrm{p}$.

4. Kabinet Ministriv Ukrajiny (2016). Pro zatverdzhennja Derzhavnoji ciljovoji socialjnoji proghramy «Molodj Ukrajiny» na 2016-2020 roky [On approval of the State Target Social Program «Youth of Ukraine» for 2016-2020]: postanova vid 18 ljut. 2016 r. № 148. URL: https://zakon.rada.gov.ua/laws/show/148-2016$\% \mathrm{D} 0 \% \mathrm{BF}$ (accessed 12 October 2019). 